MAR 291968

\title{
MULTIMEGAWATT THERMIONIC REACTOR SYSTEMS
}

FOR SPACE APPLICATIONS

C. D. Sawyer

P. R. Hill

D. R. Wilkins
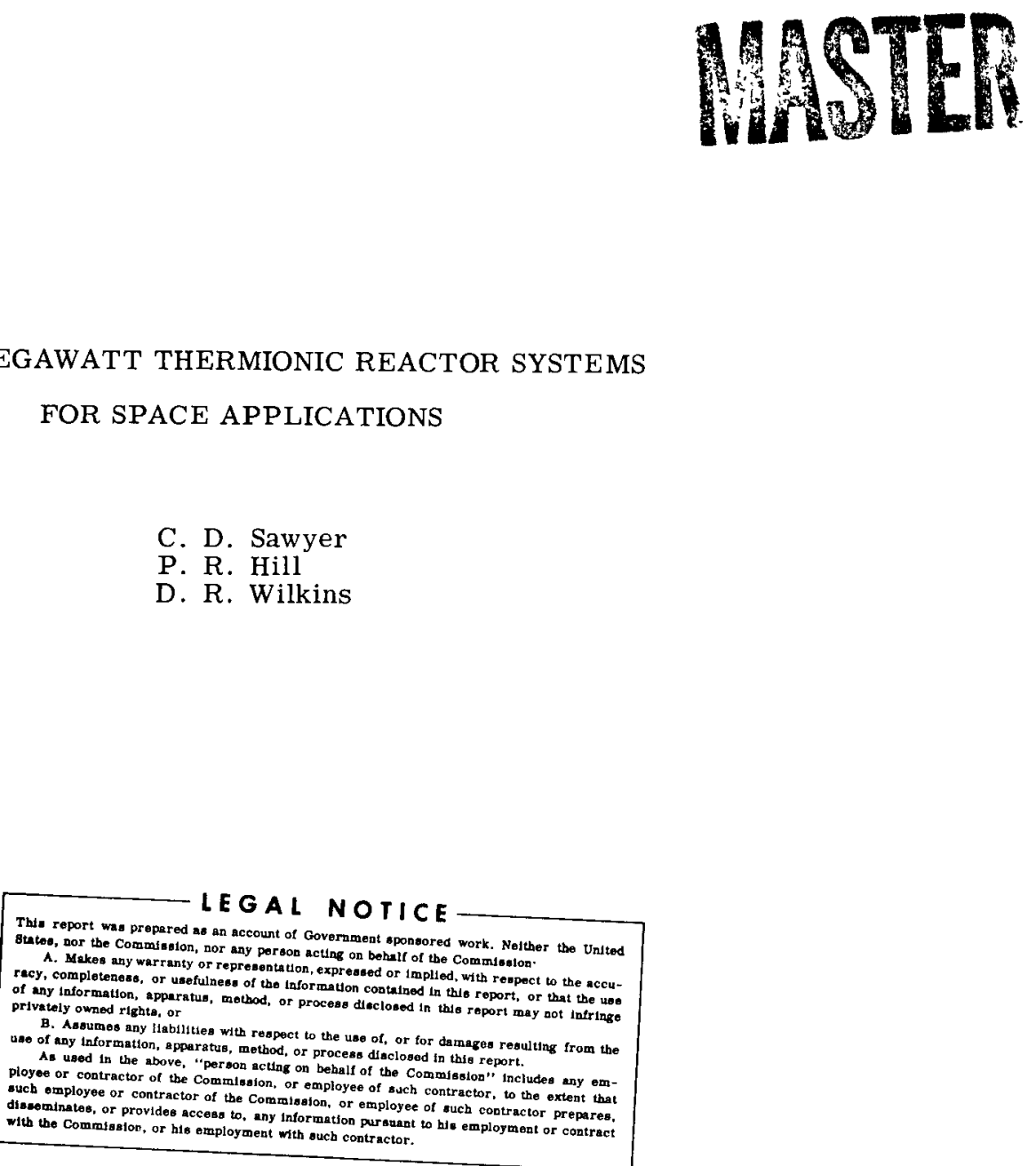

Nuclear Thermionic Power Operation

General Electric Company

Pleasanton, California

United States of America 


\section{DISCLAIMER}

This report was prepared as an account of work sponsored by an agency of the United States Government. Neither the United States Government nor any agency Thereof, nor any of their employees, makes any warranty, express or implied, or assumes any legal liability or responsibility for the accuracy, completeness, or usefulness of any information, apparatus, product, or process disclosed, or represents that its use would not infringe privately owned rights. Reference herein to any specific commercial product, process, or service by trade name, trademark, manufacturer, or otherwise does not necessarily constitute or imply its endorsement, recommendation, or favoring by the United States Government or any agency thereof. The views and opinions of authors expressed herein do not necessarily state or reflect those of the United States Government or any agency thereof. 


\section{DISCLAIMER}

Portions of this document may be illegible in electronic image products. Images are produced from the best available original document. 


\title{
MULTIMEGAWATT THERMIONIC REACTOR SYSTEMS FOR SPACE APPLICATIONS*
}

\author{
C. D. Sawyer, P. R. Hill, D. R. Wilkıns \\ General Electric Company \\ Nuclear Thermionic Power Operation \\ Pleasanton, California \\ United States of America
}

\begin{abstract}
A review of selected portions of the General Electric Company thermionic reactor development program is presented Typical design features and performance characteristics of thermionic reactors with electrical ratings in the multimegawatt class are presented by reference to the results of a reactor design study carried out for a hybrid nuclear rocket/nuclear electric Mars mission. Important elements of related technology from other elements of the General Electric program are also presented In particular, a summary of the results of a thermionic reactor critical experiment and the results of preliminary reactor stability studies is discussed
\end{abstract}

\section{REACTOR DESIGN STUDIES}

In the development of the technology of the nuclear thermionic reactor concept, primary attention has been given to the technology of the thermionic converter, high temperature materials, and the fabrication and test of thermionic devices using nuclear heating. Since there are several concepts of thermionic reactors, and each differs in content and priorities in its respective development programs, it is important to examine the potential applications of each to identıfy more clearly the major problems to ensure that the programs are being directed effectively toward the desired goal. It is essential to define the intended application of the power system and to interpret the various interactions and constraints which connect the application and the power system into an effective power plant design The use of the thermionic reactor to provide large quantities of electrical power to an electrical propulsion system for high energy, long time space missions is a particularly attractive example of the potential application of nuclear thermionic power systems.

\section{POWER PLANT CONCEPT}

A conceptual arrangement of the thermionic reactor and the other major power plant components is shown in Fig. 1. The thermionic reactor with its shadow shield is located at the apex of a conical radiator. The shield is split to accommodate an intermediate heat exchanger and the pumps which circulate liquid metal through the reactor cooling loop. Actuating motors for the reactor control elements could be located at this place or with the balance of the power plant auxiliaries on the tar side of the equipment shield. Auxiliaries include the liquid metal circulating pumps tor the radiator loop and the instrumentation and control package which provide for over-all control of the reactor and power plant. Also included is the power conditioning equipment with its cooling system. This equipment provides for conversion of the low voltage direct current output from the thermionic fuel elements (TFEs) to power plant distribution voltage. A number of variations upon this arrangement (Fig. 1) may be considered. The optimum arrangement will almost certainly depend upon the specific application and the particular characteristics and limitations of the boost vehicle used.

* This work was supported by the National Aeronautıcs and Space Administration and the United States Atomic Energy Commission. 


\section{REACTOR CONCEPT}

A section of the reactor in a plane containing the reactor central axis is shown in Fig. 2. At the shield end of the reactor the coolant plenum, which collects the core exit flow, is penetrated by the TFE sheath extensions containing the electrical leads and cesium vapor supply passages. These extensions penetrate the reactor vessel head through welded closures. The metal-to-ceramic seals located external to the face of the reactor vessel head permit access to the electrical lead and form a closure to the cesium vapor envelope. In addition, this region also contains the electrical connectors and $\mathrm{C}_{\mathrm{S}}$ vapor supply system Reactor control is achieved by motion of segments of the radial reflector which consists of $4 \mathrm{in}$ of Be immediately adjacent to the external lateral surface of the reactor vessel.

The reactor core consists of bundles of TFEs in a hexagonal configuration (Fig. 3) The bundle consists of a 40-mil hexagonal stainless steel can holding two or more rings of fuel elements Spacer and filler elements serve the dual function of spacing and restraining the fuel elements while also divertıng coolant flow to provide uniform cooling around the sheath circumference Coolant flow is controlled by triangular spacers in the cusp-shaped region around the periphery of the fuel bundles and by small circular spacers in the internal cusp-shaped region between each fuel element. Contact between the spacers, and the fuel elements is limited to small local regions of projections and ridges in the spacers and the fuel element sheath The dual function of these spacers is important in restraining thermally or mechanically induced motion of the fuel elements which could introduce serious reactivity fluctuations and result in reactor instability The improvement in flow distribution helps suppress instability by reducing the thermal gradients in the sheath which cause motion and also reduces stress levels in the sheath and insulator assembly caused by the nonuniform sheath temperature

The fuel element bundles are arranged into an approximately circular cross section in a cylindrical reactor vessel. Coolant flows in two passes through the vessel with the flow proceeding down through the annulus between the core and reactor vessel wall and returning up through the core. The coolant inlet and outlet pipes are located at the shield end of the reactor.

The essential features of the TFE are shown in Fig. 4, the materials and dimensions of the TFE are.

\begin{tabular}{|c|c|c|c|c|c|c|c|}
\hline Item & Material & Thickness & $\begin{array}{l}\text { Outside } \\
\text { Diameter }\end{array}$ & Item & Material & Thickness & $\begin{array}{c}\text { Outside } \\
\text { Diameter }\end{array}$ \\
\hline Sheath & Kovar & 0020 & 0.60 & Gap & Cs Vapor & 0.007 & ---- \\
\hline Insulator & $\mathrm{Al}_{2} \mathrm{O}_{3}$ & 0.020 & $\ldots$ & Emitter & & 0.030 & $\ldots-\ldots$ \\
\hline Collector & $\mathrm{Nb}^{2}$ & 0.020 & ---- & Fuel & $\mathrm{UO}_{2}$ & $-\ldots$ & 0.406 \\
\hline
\end{tabular}

These dimensions were selected on the basis of the results of previous optımızation studies. The most important variable here is the sheath diameter of the TFE which is selected to maximize the emitter area density in the core. The 0.6 -inch value represents the practical optimum, the mathematical optimum yielded values of sheath diameter below that considered favorable in the fabricatıon sense. The values of material thicknesses are selected at the minimum practical value except for emitter and collector. Optimization of the emitter and collector thickness involve cell length, emitter area density, fuel volume fraction, and electrode voltage loss. The thicknesses shown here reflect fabrication and reliability considerations, but are near optimum values. Emitter length is then established by selecting an arbitrary $5 \%$ loss of voltage in the electrodes for the 
thermionic design point selected. The precise optimum is believed to be in the range of 3 to $10 \%$ and causes relatively small variations in over-all system characteristics in this range.

\section{ELECTRICAL DESIGN CONSIDERATIONS}

The thermionic reactor consists of numerous converter cells each operating at a relatively low output voltage. Since this voltage for each cell is usually less than $1 \mathrm{~V}$, the need for series connections to limit the reactor output current becomes quite apparent. The TFE concept already provides series-connected groups of 12 or more cells. Further advantages might be obtained if more series connections of TFEs were provided (e.g., lower weight of power cables between the reactor and power conditioning equipment, and more efficient, lightweight power conditioning equipment).

On the other hand, the series connection of TFEs for voltage buildup could adversely affect reliability. Some upper limit on voltage across the TFE sheath insulator exists and should not be exceeded to prevent insulator breakdown and arcing to ground. The mechanical design of the reactor is made more complex by requiring internal electrical connections, or penetrations of the reactor vessel at both ends for TFE electrical series connections. In addition, the consequences of an open circuit failure become increased in proportion to the number of TFEs which are series connected.

For the reactor designs being investigated, the design choice involves grounding the end of the TFEs internal to the reactor while alternating the output voltage of pairs of TFEs positive and negative about ground (Fig. 5). The circuit diagram shown here implies that pairs of positive and negative TFEs have individual power cables and power conditioning modules. While this approach can potentially provide a degree of redundancy in the power conditioning system and result in improved over-all reliability, it may be desirable to consider paralled-connected groups of TFEs connected to a single power conditioning module in terms of weight, efficiency, or complexity. Further study is required to make this choice.

This method of connecting pairs of TFEs results in effectively series-connecting two TFEs without requiring internal electrical connections or additional vessel penetration. The maximum voltage across the sheath insulator is one-half the effective output voltage of the core. The consequences of an open circuit failure in a TFE can be designed to cause a loss in output from only that TFE if provision is made in the power conditioning and switching circuitry.

\section{BACKGROUND TECHNOLOGY}

The background technology of this study in the area of thermionics will be covered in part in other papers presented at this conference. In particular, the information presented by Wilson ${ }^{(1)}$, VanHoomissen ${ }^{(2)}$, and Wilkins ${ }^{(3)}$ represent development knowledge and techniques which have contributed directly to the evaluation of the reactor system presented in this paper.

The results of a thermionic reactor critical experiment and studies devoted to thermionic reactor stability characteristics not previously been reported are presented next. The Thermionic Reactor Critical Experiment (TRCE) ${ }^{(6)}$ was directed toward an evaluation of thermionic reactor cores in the lower power range of a few hundred kilowatt electrical. The results of the 
experiment are useful in developing a better understanding of the physics of thermionic cores over a broad range of power levels.

\section{CRITICAL EXPERIMENT}

The TRCE was a small, compact, unformly reflected, fast spectrum reactor Two experımental configurations were examined. The first, a Be-reflected system, was used principally to examine experiment-to-analysis correlations. The second, performed on Be-and stainless-steelreflected systems was directed more toward investigating the influence of reflector variations.

Physically, the TRCE was positioned in the hexagonally shaped cells of the Al matrix of a hor zontally oriented split table assembly, one table was fixed and the other movable (Fig. 6). The basic cell structure consisted of stacked hexagonal Al tubes with a nominal spacing of 1.785 inches across the flats. The Al walls of the tubes were 0.031 inch thick. Six inches of the 14.76-1nchlong core was in the fixed table. An axial layout of the initial configuration, Configuration A, is shown in Fig. 7. The loading of each hexagonal cell within the core and transition region was done with small diameter $(\sim 0.18 \mathrm{mch})$ rods, and the loading of the reflector region was done with full and half-hex size pieces.

There were five variations of the basic configurations studied. Configuration A consisted of a 0.875-inch-thick transition region surrounding the core and a nominal 6-inch Be radial and axial reflector and made as symmetric a system as was practical In Configuration B1 the axial transition region was removed and the axial reflector modified to include a significant amount of stainless steel to make the axial direction conform to a situation thought to be more typical of the end reflectors of a thermionic reactor design. In the remaining configurations (Table 1) the influence of the composition and dimension of the radial reflector was investigated

A summary of loading data for the five configurations is presented in Table 1. Modifications of published cross section data ${ }^{(4)}$ were used with $\mathrm{S}_{4}$ quadrature.

Typical power profiles in the radial and axial directions and the calculated results are shown in Fig. 8 and 9. The discrepancy in the axial profile is attributed to a marked streaming effect by reflected low energy neutrons in this direction. The stainless-steel-reflected cores exhibited power profiles with a much smaller minimum-to-centerline power ratio and no peaking at the core edge. Gross spectral determinations were made by fission ratios

\begin{tabular}{|c|c|c|c|c|c|c|c|}
\hline \multirow[b]{2}{*}{ lement } & \multicolumn{2}{|c|}{ Configuration A } & \multirow{2}{*}{$\begin{array}{c}\text { Configuration B4 } \\
\text { Calculated }\end{array}$} & \multirow[b]{2}{*}{ Element } & \multicolumn{2}{|c|}{ Configuration A } & \multirow{2}{*}{$\begin{array}{c}\text { Configuration B4 } \\
\text { Calculated }\end{array}$} \\
\hline & Calculated & Measured & & & Calculated & Measured & \\
\hline $\begin{array}{l}\mathrm{T}-232 \\
\mathrm{U}-233 \\
\mathrm{U}-238\end{array}$ & $\begin{array}{l}1 . \\
0.019 \\
1.60 \\
0.080\end{array}$ & $\begin{array}{l}1 . \\
0.020 \\
1.47 \\
0.082\end{array}$ & $\begin{array}{l}1 \\
0.021 \\
1.61 \\
0.087\end{array}$ & $\begin{array}{l}\mathrm{Np}-237 \\
\mathrm{Pu}-239 \\
\mathrm{Pu}-240\end{array}$ & $\begin{array}{l}0.47 \\
0.99 \\
052\end{array}$ & $\begin{array}{l}0.50 \\
1.10 \pm .07 \\
0.50\end{array}$ & $\begin{array}{l}0.50 \\
1.00 \\
0.56\end{array}$ \\
\hline
\end{tabular}


TABLE 1. Summary of Loading Data for TRCE

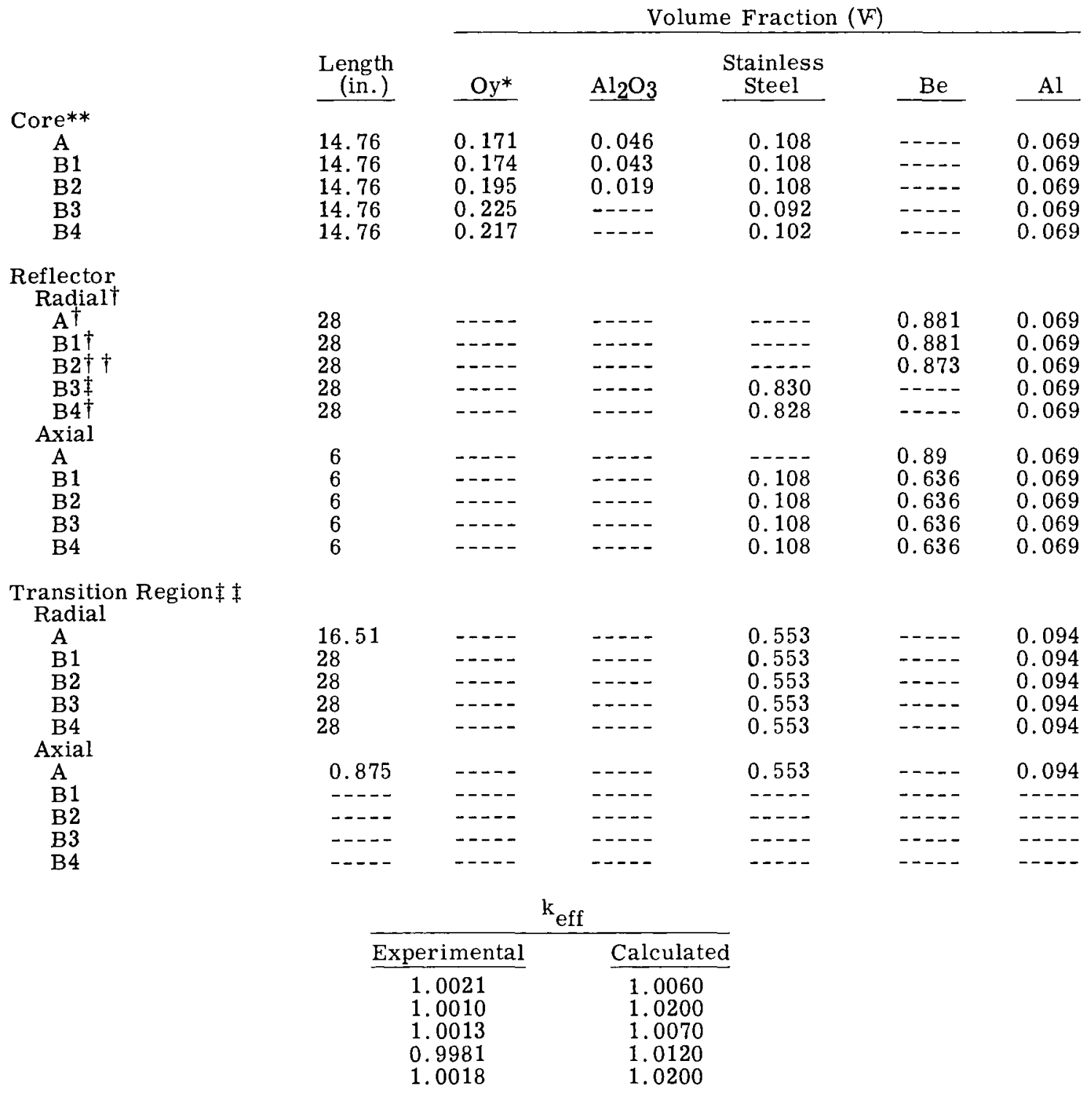

V Volume fractions of theoretically dense materials

* Oralloy, density $18.8 \mathrm{gm} / \mathrm{cm}^{3}$ at 93.2 at. $\% \mathrm{U}-235$

** All cores contain $\mathrm{F}\left(\mathrm{WO}_{3}\right)=0.311 \mathrm{~V}(\mathrm{Ni})=0.070$

$\dagger 6.15$ in. thick

$\dagger \dagger 3.52$ in. thick

$\ddagger 4.4$ in. thick

本 0.875 in. thick

There is general agreement between measurement and calculation for the threshold detections which indicates a reasonable spectral determination in the calculations. The discrepancies in the $\mathrm{U}-233$ and $\mathrm{Pu}-239$ ratios are indicatative of the present precision of high energy fission cross section data for these isotopes. 
Neutron lifetime measurements were made by both the Rossi-alpha technique and by the $1 / \mathrm{V}$ poisoning technique. For TRCE-A, the neutron lifetime was $9.4 \pm 0.9 \mu$ sec and for TRCE-B4 it was $0.6 \pm 0.1 \mu \mathrm{sec}$.

Material worth measurements were performed on various materials both at core centerline and for core average (core length samples). A selection of experimental results obtained on Configuration $\mathrm{A}$ are:

\begin{tabular}{lc} 
Material & Worth $(\% \Delta \mathrm{k} / \mathrm{gm})$ \\
\cline { 3 - 3 } $\mathrm{Ni}$ & $+1.3 \times 10^{-5}$ \\
Stainless Steel & $+3.8 \times 10^{-5}$ \\
$\mathrm{Nb}$ & $<10^{-6}$ \\
$\mathrm{Mo}$ & $+1.6 \times 10^{-5}$
\end{tabular}

\begin{tabular}{c} 
Material \\
\hline W \\
Re \\
Ta \\
--
\end{tabular}

\begin{tabular}{c} 
Worth $(\% \Delta \mathrm{k} / \mathrm{gm})$ \\
\hline$-1.3 \times 10^{-5}$ \\
$-2.3 \times 10^{-4}$ \\
$-1.2 \times 10^{-4}$ \\
------
\end{tabular}

Reflector replacement studies also included a $60^{\circ}$ sector of radial reflector replaced by BeO in Configuration A. This indicated a lower power peaking at the core edge and an extrapolated gain of $2.4 \%$ $\Delta \mathrm{k}$ for a radial BeO reflector. Preliminary control element studies were also made and the effect of a $4.4-\mathrm{cm}$ displacement of a $60^{\circ}$ radial sector of reflector was measured. This displacement produced $2.1 \% \Delta \mathrm{k}$ and $1.5 \% \Delta \mathrm{k}$ reductions in reactivity for TRCE-A and TRCE-B4, respectively.

\section{REACTOR STABILITY}

A detailed analysis of the stability characteristics of the thermionic reactor was preformed. The nonlinear differential equations which describe time-dependent phenomena in the reactor components were linearized about an appropriate operating point, and written in matrix form. The eigenvalues of the system matrix were evaluated numerically to determine the stability properties of the system, and key stability parameters were identified through a series of parametric studies. In this manner, it was determined that two key stability parameters in a thermionic reactor are the fuel and emitter temperature coefficients of reactivity, $\alpha_{F}$ and $\alpha_{E}$, respectively. Approximate stability criteria for these parameters were derived from a two-region reactor model, and were in excellent agreement with the numerical results. These criteria are:

$$
\alpha_{E} \leq-\left(1+\mathrm{H}_{\mathrm{E}} / \mathrm{H}_{\mathrm{FE}}\right) \alpha_{\mathrm{F}} ; \quad \alpha_{\mathrm{E}} \geq\left(\mathrm{C}_{\mathrm{E}} / \mathrm{C}_{\mathrm{F}}\right) \alpha_{\mathrm{F}}-\gamma ; \gamma=\left(\tau \mathrm{H}_{\mathrm{E}} / \mathrm{P}_{\mathrm{T}}\right)\left[\mathrm{H}_{\mathrm{FE}} / \mathrm{C}_{\mathrm{F}}+\left(\mathrm{H}_{\mathrm{FE}}+\mathrm{H}_{\mathrm{E}}\right) / \mathrm{C}_{\mathrm{E}}\right]
$$

where $\mathrm{C}_{F}$ and $\mathrm{C}_{\mathrm{E}}$ are the fuel and emitter heat capacities, respectively; $\mathrm{H}_{\mathrm{FE}}$ and $\mathrm{H}_{\mathrm{E}}$ are the fuelemitter and emitter-collector heat conductances, respectively; $\tau$ is an "effective neutron lifetime;" and $\mathbf{P}_{\mathrm{T}}$ is the steady-state thermal power of the reactor. An approximate requirement for the reactor to be stable is that the sum of the fuel and emitter temperature coefficients of reactivity be negative. Computations of the Doppler coefficients for the small reactor design yield $\alpha_{\mathrm{F}}=+1.0 \times 10^{-7} /{ }^{\circ} \mathrm{K}$ and $\frac{\alpha}{\mathrm{E}}=-6.0 \times 10^{-7} /{ }^{\circ} \mathrm{K}$. On this basis, it is concluded that such reactor designs are stable.

\section{PARAMETRIC STUDIES}

Parametric studies were made for the reactor concept described in this paper. Reactor electrical output was varied over the range of a few thousand to twenty thousand kilowatts electrical output, for the two levels of converter electrical performance shown on the following page. At each reactor power level, the effects of core length-to-diameter ratio, the TFE bundle size, the reactor coolant pressure drop and temperature rise, and the effects of $\mathrm{Na}$ in place of $\mathrm{NaK}$ were investigated 
for all appropriate combinations and permutations. Reactor criticality was not considered in this study since for all reactor sizes above a few thousand kilowatts electrical output criticality is not limiting. The study also assumed that the fission power distribution had been flattened so that each converter cell throughout the core produced the same thermal power. The primary range of interes. this study involves core sizes for which power flattening can be achieved to a very high degree; therefore, reactor physics evaluations may be deferred until electrical, thermal, and mechanical design considerations are resolved. The studies were primarily directed toward reactor geometry and weight and performed so that core designs involving integral numbers of fuel bundles having a favorable core pattern and integral numbers of converter cells in each TFE were specified. This constraint along with the fixing of electrical performance results in reactors which do not always have the exact electrical output desired. The studies also incorporate a variety of thermal and hydraulic design criteria developed in related programs so that this aspect of the design is also adequate.

\begin{tabular}{lccc} 
& \multicolumn{2}{c}{ Converter } \\
Parameter & & Standard & Advanced \\
Temperature, ${ }^{\circ} \mathrm{K}$ & & & \\
Emitter & & 1828 & 2130 \\
Collector & 975 & 1080 \\
Cesium & 593 & 633 \\
Emitter Length, in. & 1.114 & 0.835
\end{tabular}

$\begin{array}{lccc}\text { Parameter } & & \text { Standard } & \text { Advanced } \\ \text { Current, A/cm } & & 9.0 & \\ \text { Net Voltage, V } & & 0.63 & 0.86 \\ \text { Net Output, W/cm }{ }^{2} & & 5.64 & 15.5 \\ \text { Cell Efficiency, \% } & 14.8 & 18.3\end{array}$

The thermionic performance data used in the reactor parametric studies were taken from the work of Wilson. ${ }^{(5)}$ For the "standard" converter, a low emitter temperature of $1828^{\circ} \mathrm{K}$ was selected while an emitter temperature of $2130^{\circ} \mathrm{K}$ was selected to represent a more "advanced" level of converter performance. In both cases, the individual converter cell has been optimized for voltage and thermal losses and output current density to yield maximum over-all cell efficiency. The selection of maximum cell efficiency minimized the size and weight of the heat rejection system. Selection of current densities which maximize thermionic electric power density would result in reductions in reactor and shield size, but at the expense of conversion efficiency. The true optimum is somewhere between these limiting cases, and experience indicates selection of the maximum efficiency condition is more nearly the optimum condition for large power plants.

Figure 10 represents a summary of the results of the reactor design calculations. Clearly, the most important parameter is emitter temperature level with reactor power level being second in importance. The variation with power level presented here is an underestimate since the calculated reactor weight assumes a full fuel loading in the available fuel volume. For the lowest power levels, this is appropriate, but at higher power levels less fuel would be loaded so that the actual specific weight is slightly less than that shown. The influence of all other parametric variations is small in terms of specific weight covering a range of about $\pm 5 \%$ about the mean line for the total range of parametric variations considered. The implication of these results is a strong incentive to select the best possible level of thermionic performance. Other reactor parameters may be selected on the basis of considerations other than reactor specific weight.

The results presented in Fig. 10 provide no information relative to the selection of the reactor coolant outlet temperature. This temperature essentially determines the converter collector temperature and the radiator temperature. Maximum thermionic electrical power density and conversion efficiency for a fixed emitter temperature was found as collector temperature is varied. As before, high-power density lowers reactor and shield weight while high conversion efficiency and increased collector temperature lower heat rejection system weight. Evaluation of the optimuin 
coolant temperature requires consideration of the total system. To accomplish this optimization, a simple version of the configuration shown in Fig. 1 was assumed. Trade-offs in reactor, shield, and radiator weights were examined for this configuration as reactor coolant temperature was varied.

Figure 11 presents the weight variation of the major groups of system components and total system specific weight variation for two levels of radiator technology. Light-weight radiators yield a minimum at a collector temperature of about $1000^{\circ} \mathrm{K}$ while heavier radiators result in a minimum at collector temperatures of about $1075^{\circ} \mathrm{K}$. The influence of the decrease in conversion efficiency is seen in the radiator curve which shows an increase above $1150^{\circ} \mathrm{K}$. The implications of this result are quite profound in evaluating long-term reactor development program requirements. It is seen that very little is gained by increasing reactor outlet temperature above $1000^{\circ} \mathrm{K}$. At this level, ferrous alloy technology can be used as the basis for reactor design. It does not appear that . increases in this temperature would result in significant performance improvements. While it must be recognized that future developments in thermionic technology may alleviate the fall off in conversion efficiency with increasing collector temperatures, extension of heat transfer system technology into the range beyond $1000^{\circ} \mathrm{K}$ does not appear to be required for the thermionic reactor concept.

\section{REFERENCE DESIGN}

The information developed in the reactor parametric studies and in the coolant temperature optimization studies were used to identify a reference reactor design of $3880 \mathrm{kWe}$ capacity. The configurational features of this reactor are:

$\begin{array}{lc}\text { Number of Fuel Bundles } & 73 \\ \text { Number TFE's } & 1387 \\ \text { Design UO } 2 \text { Loading, kg } & 700 \\ \text { Over-all Diameter at Active Core, inches } & 40.0 \\ \text { Hexagonal Bundle Pitch, inches } & 3.04 \\ \text { Radial Reflector Thickness, inches } & 4\end{array}$

Reactor Vessel Outside Diameter at Active Core, inches

Over-all Length to End of Leads, inches

Active Core Length, inches

Axial Reflector Length (Lower), inches Axial Reflector Length (Upper), inches
31.3

Each fuel element has 37 converter cells stacked up in series for a total of 51,319 converters in the entire core. At the upper end of the reactor, space is required for the coolant pipes, structural members, electrical connections and power cables, and the Cs vapor supply system.

The performance parameters of great interest for the reference reactor are:

$\begin{array}{lr}\text { Emitter Temperature, }{ }^{\circ} \mathrm{K} & 2,000 \\ \text { Collector Temperature, }{ }^{\circ} \mathrm{K} & 1,075 \\ \text { Average Thermionic Output, W/cm } & 9.2 \\ \text { Voltage, V } & 51.4 \\ \text { Current, A } & 75,500\end{array}$

Average Cell Efficiency, \%

Electrical Output, Reactor Terminals, $M W(e)$

Reactor Outlet Temperature, ${ }^{\circ} \mathrm{K} \quad 1,000$

Reactor Pressure Drop, psi 10
13.8

3.88

For this reactor, a converter performance level of $2000^{\circ} \mathrm{K}$ has been selected in recognition of the important benefits provided in comparison with the minimum emitter temperature of $1828^{\circ} \mathrm{K}$ considered in the parametric study. The reactor electrical output is $3880 \mathrm{~kW}$ at $51.4 \mathrm{~V}$ and $75,500 \mathrm{~A}$ at the reactor output terminals. The heat production rate in the reactor core is approximately $28,000 \mathrm{kWt}$.

The weights of various reactor components and the total reactor weight are on the following page. The TFEs are the dominant contribution to the reactor weight. This is characteristic of an efficient design since the objective is generally to maximize fuel fraction or maximize emitter area density 
or some compromise between the two. The reflectors are relatively light primarily because of the very low density of $\mathrm{Be}$.

\begin{tabular}{lr} 
TFE & 5,550 \\
Core Structure, lb & 850 \\
Reactor Vessel, lb & 650 \\
NaK Coolant Inventory, lb & 630 \\
Control Units, lb & 350 \\
Radial Reflector, lb & 1,240 \\
Axial Reflector, lb & 150 \\
\multicolumn{1}{c}{ Total Pounds } & 9,420
\end{tabular}

\section{CONCLUSIONS}

Comprehensive reactor optimization studies were made and included the interactions of geometry, thermal design, hydraulic design, and thermionic performance. The results indicated that the reactor size and weight were established primarily by the electri-

cal power output required and the thermionic performance. The geometric parameters of the reace.g., core length-to-diameter ratio and fuel element bundle size may be selected on the basis of influences other than those of reactor size and weight. In addition, coolant temperature optimization studies indicate that the benefits of increasing reactor coolant outlet temperature beyond $1000^{\circ} \mathrm{K}$ are minimal within the limits of present knowledge. This important result permits the consideration of a reactor development program which avoids the problems inherent in high-temperature refractory metal heat-transfer systems.

The temperatures and material of the thermionic converter have been chosen as a result of extensive thermionic development programs for both electrically and nuclearly heated test devices. Liquid metal system conditions and materials have been chosen to remain within the bounds of existing technology. The reactor core design incorporates the structural features required to provide the required mechanical, hydraulic, and nuclear characteristics.

Finally, the weight, size, and efficiency of this reactor represent attractive performance levels. The values presented are believed to be realistic and represent a design which provides for all the reactor requirements that can be recognized at this time. The ability to achieve the level of thermionic performance required has been and can be demonstrated in test devices with confidence. The achievement of this same level of performance in large scale thermionic fuel elements appears to be completely feasible. Accomplishing the degree of power flattening required in the core will present reactor development problems, but no technological barrier to accomplishing the required goal can be identified. The thermionic reactor core with its very high redundancy which results from its incorporation of numerous inherently long-lived thermionic converters should provide a power system of great reliability.

\section{REFERENCES}

1. Wilson, V. C., "Second International Conference on Thermionic Electrical Power Generation," Stresa, Italy, May 1968.

2. VanHoomissen, J. E. and Holtslag, D. J., Ibid.

3. Wilkins, D. R., Sawyer, C. D., and Hill, P. R., Ibid.

4. Bondarenko, I. I., et al., "Group Constants for Nuclear Reactor Calculations," Consultants Bureau, N. Y., 1964.

5. Wilson, V. C. and Lawrence, J., "Operating Characteristics of Two Thermionic Converters Having Rhenium-Nickel and Tungsten-Nickel Electrodes," September, 1964.

6. Kunze, J. F., et al., Unpublished Data, August 1966, "Thermionic Reactor Critical Experiment Data Report."

7. Wilkins, D. R., "SIMCON A Digital Computer Program for Computing Thermionic Converter Performance Characteristics," January 1968, Report No. GESR-2109. 


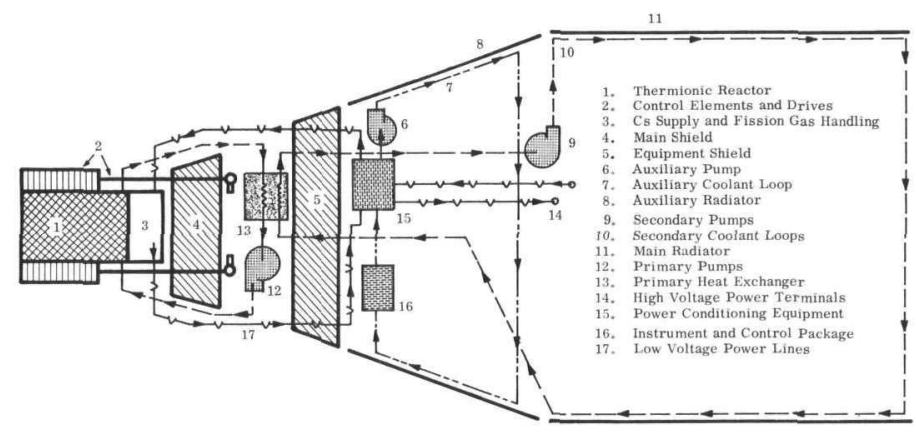

FIGURE 1. CONCEPTUAL COMPONENT ARRANGEMENT FOR A
THERMIONIC REACTOR POWER PLANT
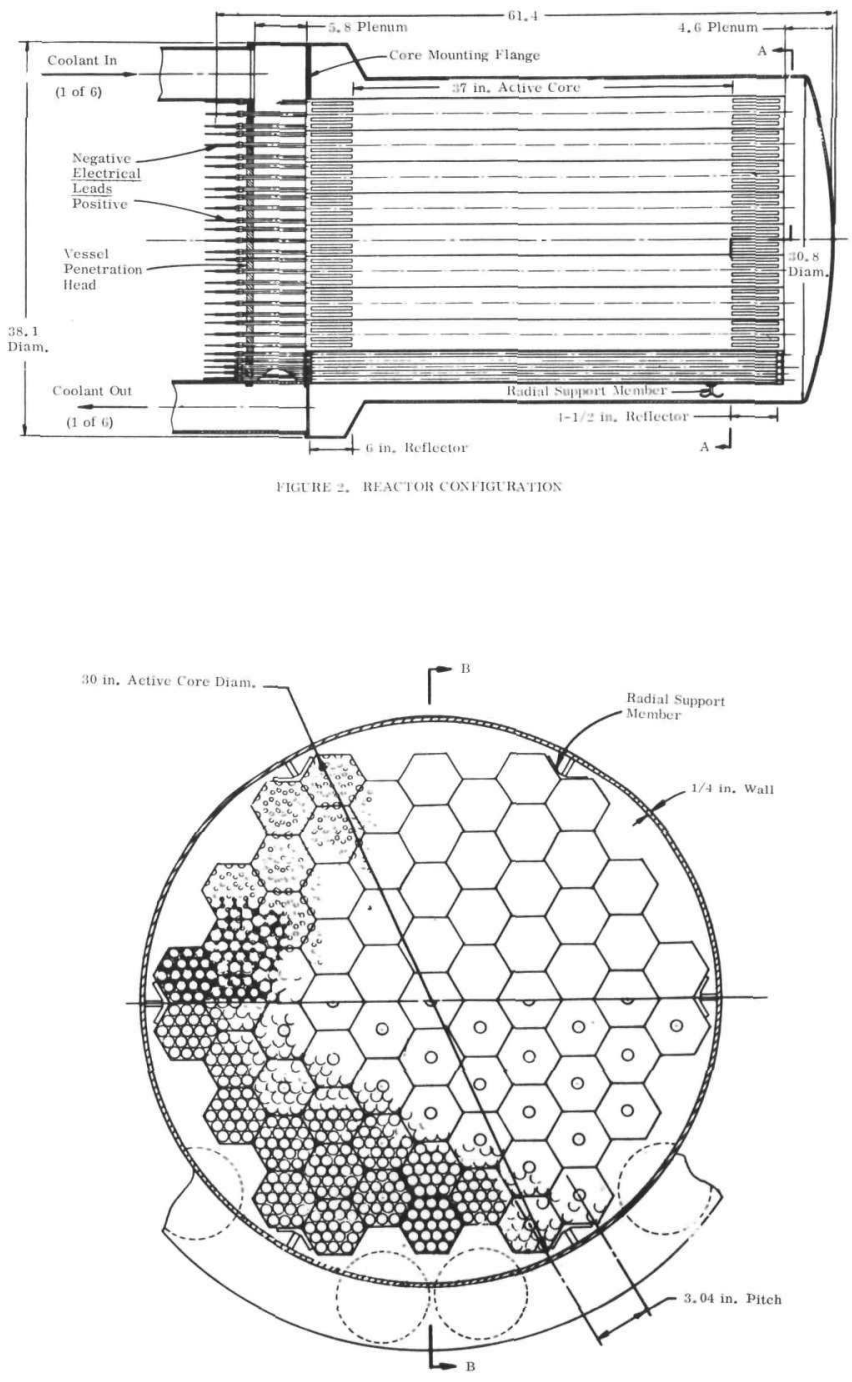

FIGURE 3. BUNDLE DRAWING 

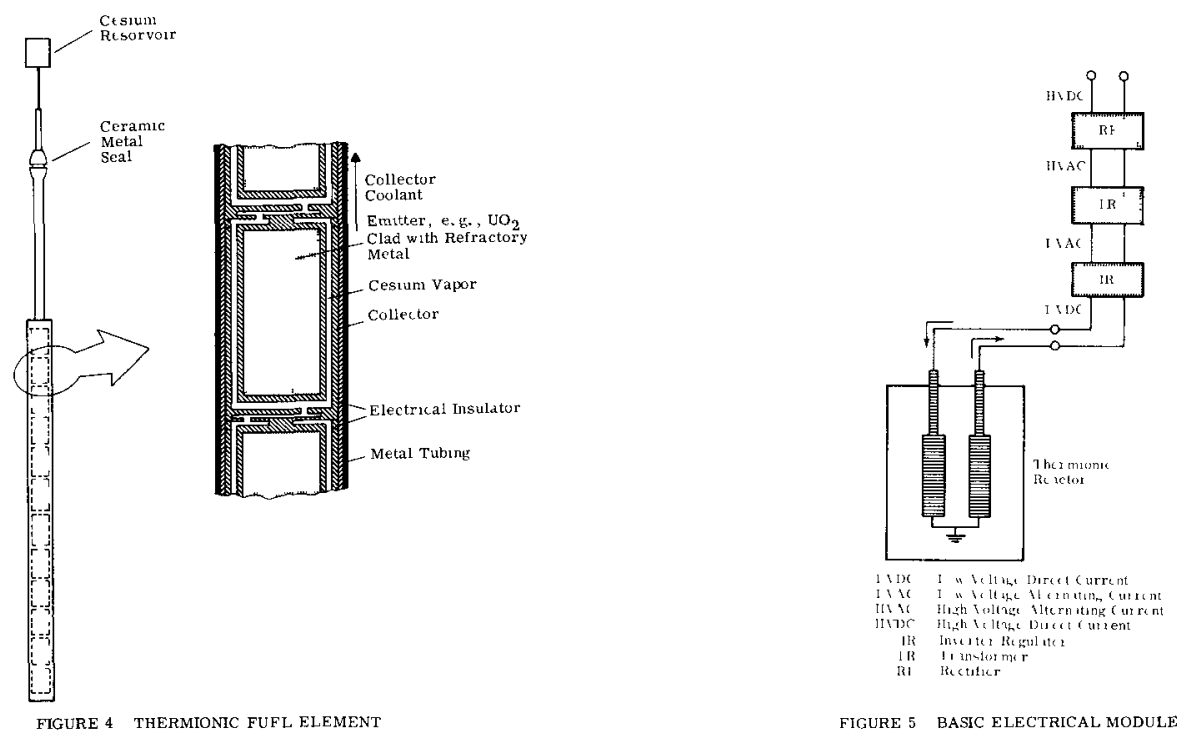

FIGURE 5 BASIC ELECTRICAL MODULE
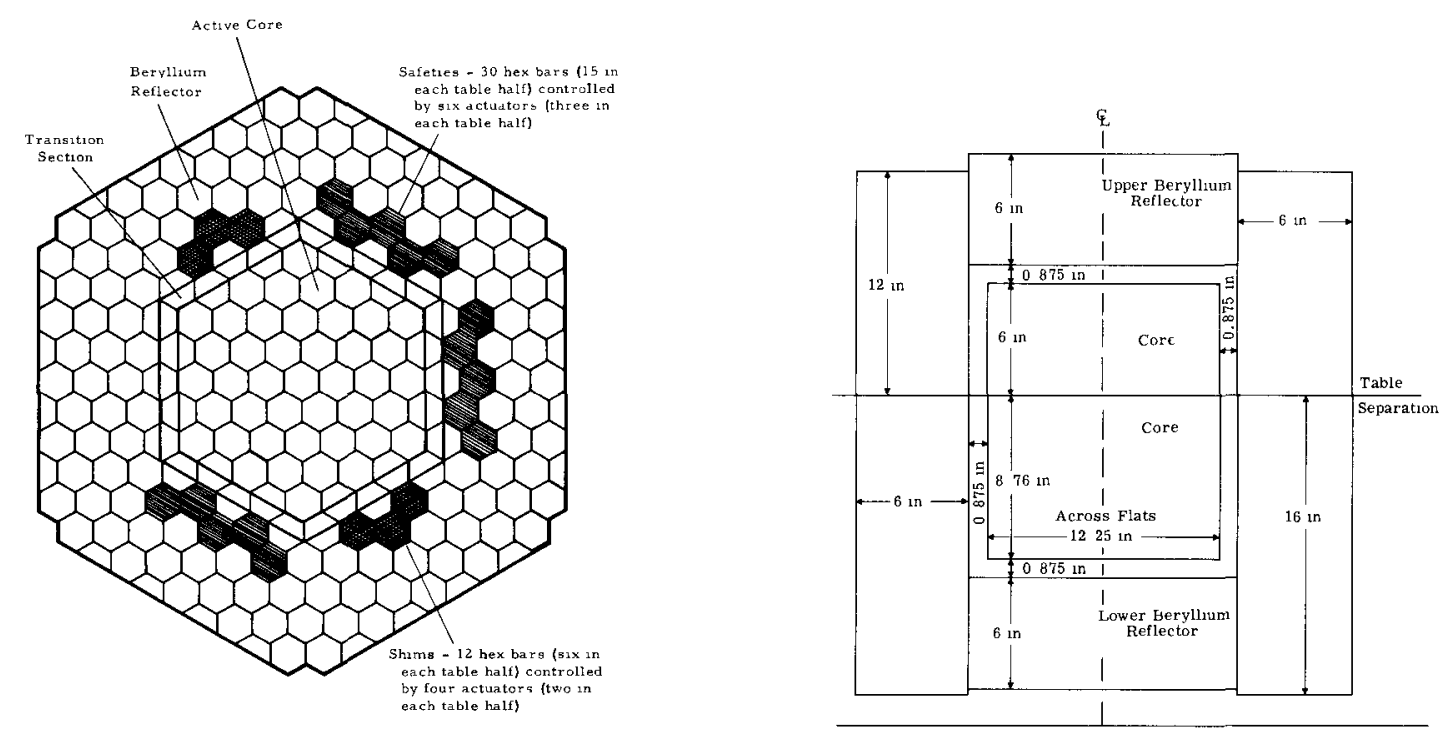

FIGURE 6, TRCE RADIAL LAYOUT

FIGURE 7 AXIAL LAYOUT OF CONFIGURATION A 


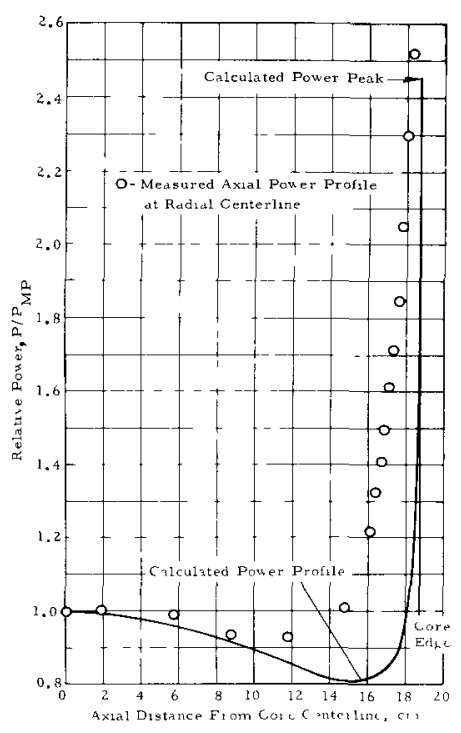

FIGURE 8. RELATIVE AXIAL POWER PROFILE CONFIGURATION A

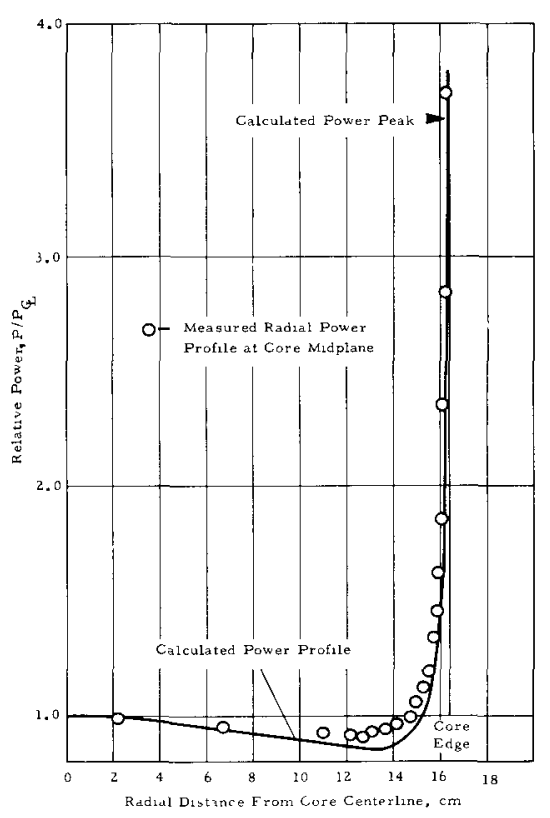

FIGURE 9 RELATIVE RADIAL POWE R PROFILE CONFIGURATION A

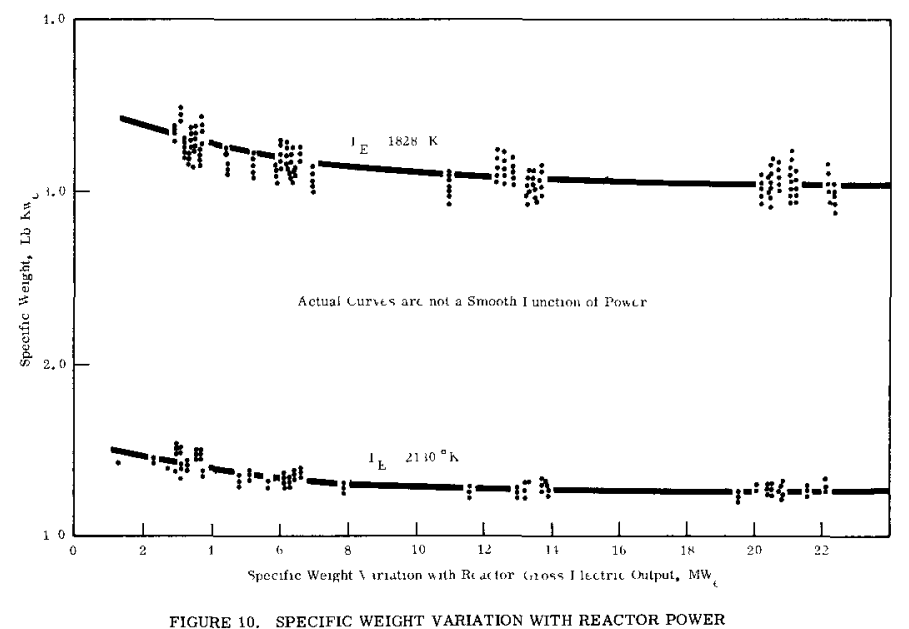

FIGURE 10. SPECIFIC WEIGHT VARIATION WITH REACTOR POWER

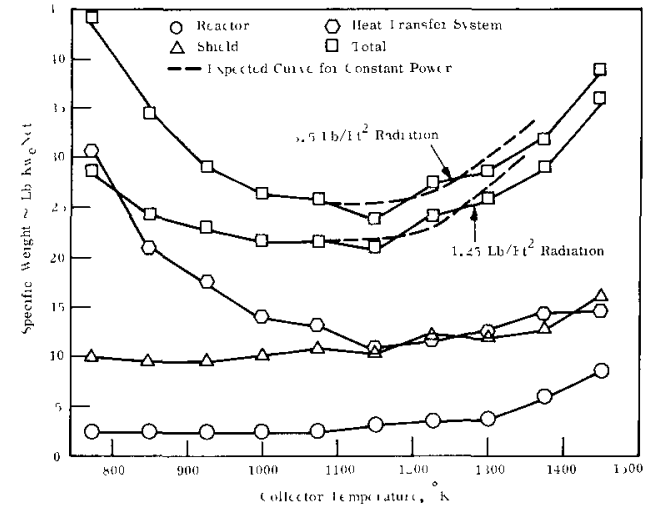

FIGURE 11 SPECIFIC WEIGHT VERSUS COOLANT TEMPERATURE 